\title{
Morphological characteristics of local entomopathogenic protozoan strains isolated from insect cadavers of certain stored-grain pests in Egypt
}

\author{
Ahlam Ahmed Alfazairy, Yasien Mohamed Gamal El-Abed, Hedaya Hamza Karam and \\ Hanan Mohamed Ramadan *iD
}

\begin{abstract}
The present study has documented, for the first time in Egypt, the natural occurrence of four entomopathogenic protozoans (EPP) among five of the most abundant and damaging insect pests of stored grains or their products. These insect pests (Laemophloeus (Cryptolestes) turcicus (Grouvelle), Rhyzopertha dominica (Fabricius), Sitophilus zeamais (Motschulsky), Tribolium castaneum (Herbst), and Plodia interpunctella (Hobner) were infesting lots of crushed-maize grains, wheat grains, and wheat flour, brought, in 2015, from El-Behera Governorate, Egypt. The morphological characteristics, including spore size, of the entomopathogen infective units, spores, of the isolated entomopathogenic protozoans, were closely fit with the description to the following genera: Mattesia, Farinocystis, Adelina, and Nosema. The prevalence of these entomopathogens ranged between 9 and $89 \%$. This study seems to be the first report of Mattesia sp. on S. zeamais; Adelina sp. on L. turcicus or R. dominica, and the second report of Nosema sp. on $R$. dominica. The rate of natural infection by the neogregarine, Mattesia sp. (tentatively, M. dispora), was the highest in L. turcicus beetles (89\%) followed by that in P. interpunctella moths (48\%), larvae (40\%), and pupae (32\%) and then in S. zeamais weevils (42\%) and R. dominica beetles with a low rate of infection (9\%). The microsporidian entomopathogen, Nosema sp., (tentatively, N. whitei) was naturally occurred in $11 \%$ of the examined adult cadavers of $R$. dominica. The coccidian entomopathogen, Adelina sp., was found, respectively, in $60 \%$ and $27 \%$ of larval and adult cadavers of T.castaneum, while the Adelina-natural infection rates in $R$. dominica and L. turcicus adult cadavers were $34 \%$ and $14 \%$, respectively. A high rate of natural infection with another neogregarine, Farinocystis sp. (tentatively, F. tribolii), has also been recorded in T. castaneum adult (50\%) or larval cadavers (36\%).
\end{abstract}

Keywords: Entomopathogenic protozoans, Stored-grain insect pests, Mattesia, Farinocystis, Adelina, Nosema, Spore dimensions

\section{Background}

Stored products as a unique habitat, present a prime opportunity to use entomopathogenic protozoans (EPP) by distributing infective quantities of the entomopathogen. Hence, controlling stored-product insect pests may be most beneficial in long-term storage since such EPP produce slow-acting chronic infection. Furthermore, they may cause a reduction in host vitality, feeding, fecundity, longevity, and survivorship (McLaughlin 1971; Khan and

\footnotetext{
* Correspondence: dhanmr@yahoo.com

Department of Applied Entomology and Zoology, Faculty of Agriculture, Alexandria University, Alexandria, Egypt
}

Selman 1989; Flinn and Schöller 2012; Ramanujam et al. 2014). Weiser et al. (1976) recorded promising examples for certain entomopathogenic protozoans that cause reductions in storage insect pests.

Literaturely, attempts to use entomopathogenic protozoans for microbial control of stored product insect pests are few. Hence, to achieve a desired suppression in populations of such insect pests, actually, more studies are required on protozoan natural infection rates in stored-product insects, and on the host range of candidate EPP. Therefore, such research approaches should be invaded. Although insect pests of stored grains and their products are among 
the most economically important pests in Egypt, there are no records on their naturally occurring EPP. Thus, as a first step in casting the light on this field, the present work was carried out, hopefully, to document the Egyptian strain(s) of the entomopathogenic protozoans, originally isolated from certain stored-grain insect pests, and their natural infection rates, as well as to describe some of the morphological characteristics of their infective units, spores.

\section{Materials and methods}

\section{Insect pests}

In August and September 2015, lots of 5-10 kg of stored-crushed maize grains, and others of wheat, wheat flour, and rice were brought from a private storehouse of stored-grains in Koom-Hamada, El-Behera, Egypt, to the Insect Pathology Laboratory, Applied Entomology Department, Faculty of Agriculture (El-Shatby), Alexandria University, Alexandria, Egypt. All lots were infested with the most abundant cosmopolitan insect pests of stored grain; namely, Laemophloeus turcicus (Grouvelle), Tribolium castaneum (Herbst), Rhyzopertha dominica (Fabricius), Oryzaephilus surinamensis (L.), Sitophilus zeamais (Motschulsky), and Plodia interpunctella (Hübner). Among the crushed-maize grain lots, infested with the flour-mill beetle, L. turcicus, two cultures have been observed. Laemophloeus beetles of the first culture were less active and completely unable to fly; also, a considerable number of naturally dead or moribund beetles were present. On the contrary, the flour-mill beetles of the second culture were active, good fliers, and a very few number of dead beetles has been observed. The first procedures of Koch's postulates (Kiraly et al. 1970) revealed a severe association of the entomopathogenic neogregarine protozoan, Mattesia sp. with Laemophloeus adults of only the first culture, whereas those of the second culture showed to be totally free of the protozoan pathogen.

\section{Natural infection rates}

Mother cultures infested with L. turcicus, T. castaneum, $R$. dominica, S. zeamais, O. surinamensis, and $P$. interpunctella, were maintained in plastic jars $(9 \times 20 \mathrm{~cm})$ supplied, separately, with crushed-maize grain, wheat, rice, and whole wheat flour. All jars were covered and closed with cotton cloth covers and rubber bands and kept at the laboratory conditions of $25.3 \pm 3.8^{\circ} \mathrm{C}, 84.2 \pm$ $3.7 \% \mathrm{RH}$, and photoperiods of ca. $12-14 \mathrm{~h}$. The naturally dead insects of these stock cultures were periodically (weekly) collected and stored in the fridge $\left(4-8{ }^{\circ} \mathrm{C}\right)$ in clean, sterilized vials. These dead insects were individually smeared in Ringer solution and microscopically examined ( $\times 100$ and $\times 400$ magnification) for Mattesia infection or other entomopathogenic protozoans. Before preparing the subject smears, dead insects were thoroughly brushed with $70 \%$ ethanol on tissue papers for surface sterilization. Mattesia-natural infection rates among the subject insect pests were recorded and compared only to both male and female beetles of Laemophloeus. Other entomopathogenic protozoans were recorded too.

\section{Spore measurements}

Mattesia, Farinocystis, or Nosema spore dimensions (length and width, in micrometers, $\mu \mathrm{m}$ ) were measured by using the micrometric lens $(\times 400$ or $\times 1000)$. The spore size was determined in both Lactophenol-mount and Ringer solution-mount preparations of infected cadavers $(n=50$ or $60 ; 5$ or 6 insects, 10 readings per insect). Infective units of the isolated EPP, in Ringer solution or Lactophenol preparations, were photographed using both light and scanning electron microscope (SEM).

\section{Statistical analysis of data}

All means obtained were compared by the adoption of the $F$ test and $t$ test at the $5 \%$ level of probability, while all probable comparisons among these means were achieved using Duncan's multiple range test, at the $5 \%$ or $1 \%$ level by adopting the computer program, SPSS 16.0.

\section{Results and discussion}

Natural mortality rates due to certain entomopathogenic protozoans among certain stored-grain insect pests in Egypt

As shown in Table 1, four EPP, Mattesia sp., Nosema sp., Adelina sp., and Farinocystis sp., were recorded among five stored-grain insect pests, $L$. turcicus, $P$. interpunctella, S. zeamais, $R$. dominica, and T. castaneum (Fig. 1).

The rate of natural infection by the neogregarine, Mattesia sp. (Fig. 2), was the highest in L. turcicus beetles (89\%) followed by $P$. interpunctella moths (48\%), larvae (40\%), and pupae (32\%) and then S. zeamais weevils (42\%) and $R$. dominica beetles with a low rate of infection (9\%).

The microsporidian entomopathogen, Nosema sp. (Fig. 3), was naturally occurred in $11 \%$ of the examined adult cadavers of $R$. dominica (Table 1 ).

The coccidian entomopathogen, Adelina sp. (Fig. 4), was found, respectively, in $60 \%$ and $27 \%$ of larval and adult cadavers of $T$. castaneum, while the Adelina-natural infection rates in $R$. dominica and $L$. turcicus adult cadavers were 34 and $14 \%$, respectively (Table 1).

A high rate of natural infection with another neogregarine, Farinocystis sp. (Fig. 5), was also recorded in T. castaneum adult (50\%) or larval cadavers (36\%).

Additionally, on the basis of sex differences, the presence of the entomopathogen, Mattesia was also detected and compared only in L. turcicus adult males and females (Fig. 1). The findings in Table 2 indicate that there is no remarkable difference between the two sexes 
Table 1 Natural mortality rates (\%) among certain insect pests of stored grain due to entomopathogenic protozoans

\begin{tabular}{|c|c|c|c|c|}
\hline \multirow{2}{*}{$\begin{array}{l}\text { Entomopathogenic protozoan } \\
\text { Mattesia sp. }\end{array}$} & \multirow{2}{*}{$\begin{array}{l}\text { Insect pest } \\
\text { Laemophloeus turcicus (Grouv.) (Coleoptera: laemophloeidae) }\end{array}$} & \multicolumn{3}{|c|}{ Natural mortality rate (\%) } \\
\hline & & $2601 / 2914$ & (89) & A \\
\hline & Plodia interpunctella (Hübner) (Lepidoptera: Pyralidae) & $\begin{array}{l}34 / 71 \\
40 / 100 \\
17 / 53\end{array}$ & $\begin{array}{l}(48) \\
(40) \\
(32)\end{array}$ & $\begin{array}{l}A \\
L \\
P\end{array}$ \\
\hline & Sitophilus zeamais (Motschulsky) (Coleoptera: Curculionidae) & $143 / 339$ & $(42)$ & A \\
\hline & Rhyzopertha dominica (F.) (Coleoptera: Bostrichidae) & $72 / 775$ & (9) & A \\
\hline Nosema sp. & R. dominica & $83 / 775$ & $(11)$ & A \\
\hline \multirow[t]{3}{*}{ Adelina sp. } & Tribolium castaneum (Herbst) (Coleoptera: Tenebrionidae) & $\begin{array}{l}73 / 275 \\
72 / 120\end{array}$ & $\begin{array}{l}(27) \\
(60)\end{array}$ & $\begin{array}{l}\mathrm{A} \\
\mathrm{L}\end{array}$ \\
\hline & R. dominica & $266 / 775$ & (34) & A \\
\hline & L. turcicus & $402 / 2914$ & $(14)$ & A \\
\hline Farinocystis sp. & T. castaneum & $\begin{array}{l}138 / 275 \\
43 / 120\end{array}$ & $\begin{array}{l}(50) \\
(36)\end{array}$ & $\begin{array}{l}\mathrm{A} \\
\mathrm{L}\end{array}$ \\
\hline
\end{tabular}

$A$ adult, $L$ larva, $P$ pupa

toward Mattesia disease, where the recorded Mattesianatural infection rates in both of $160 \mathrm{~L}$. turcicus females (90.63\%) and 144 males (90.97\%) were nearly equal (91\%). Hence, it seems that the Mattesia does not prefer any sex of the flour-mill beetle. A similar observation has been reported by Baki (2016) who found no considerable difference between sexes of Crioceris asparagi (Linne) (Coleoptera: Chrysomelidae) toward Mattesia infection.

Beetles of Laemophloeus spp. (Cryptolestes) and $R$. dominica, as well as $P$. interpunctella moth have been

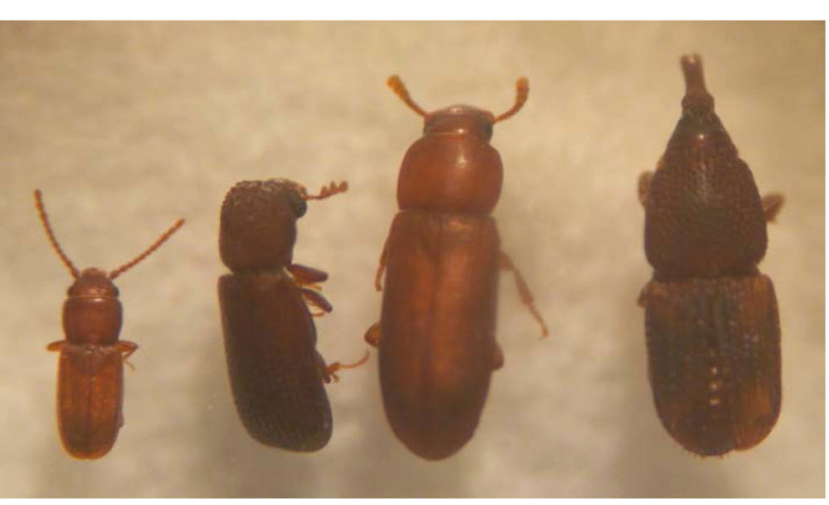

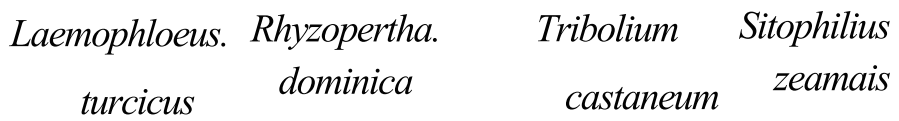
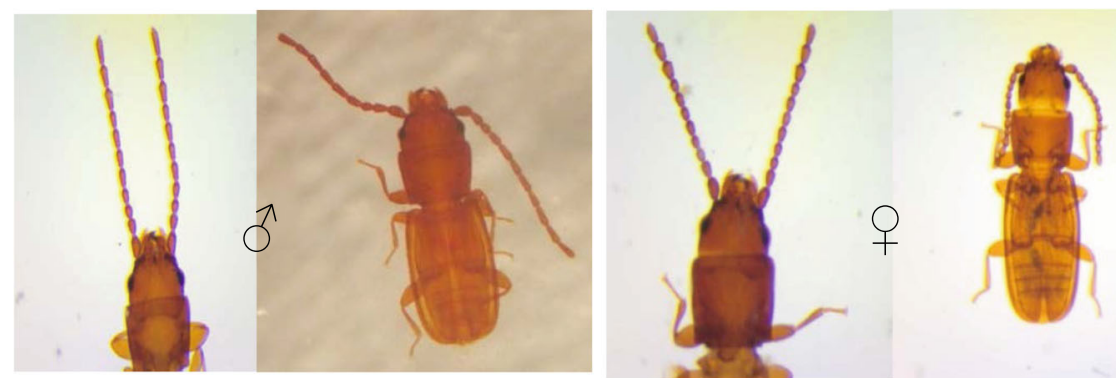

Fig. 1 The coleopterous pests associated with crushed-maize grain-laboratory cultures; ( $\times 25$ magnification). Below, Laemophlaeus turcicus adult male (left, male sign; antennae: filiform) and female (right, female; antennae: moniliform), with anterior end magnified ( $\times 100$ magnification) 


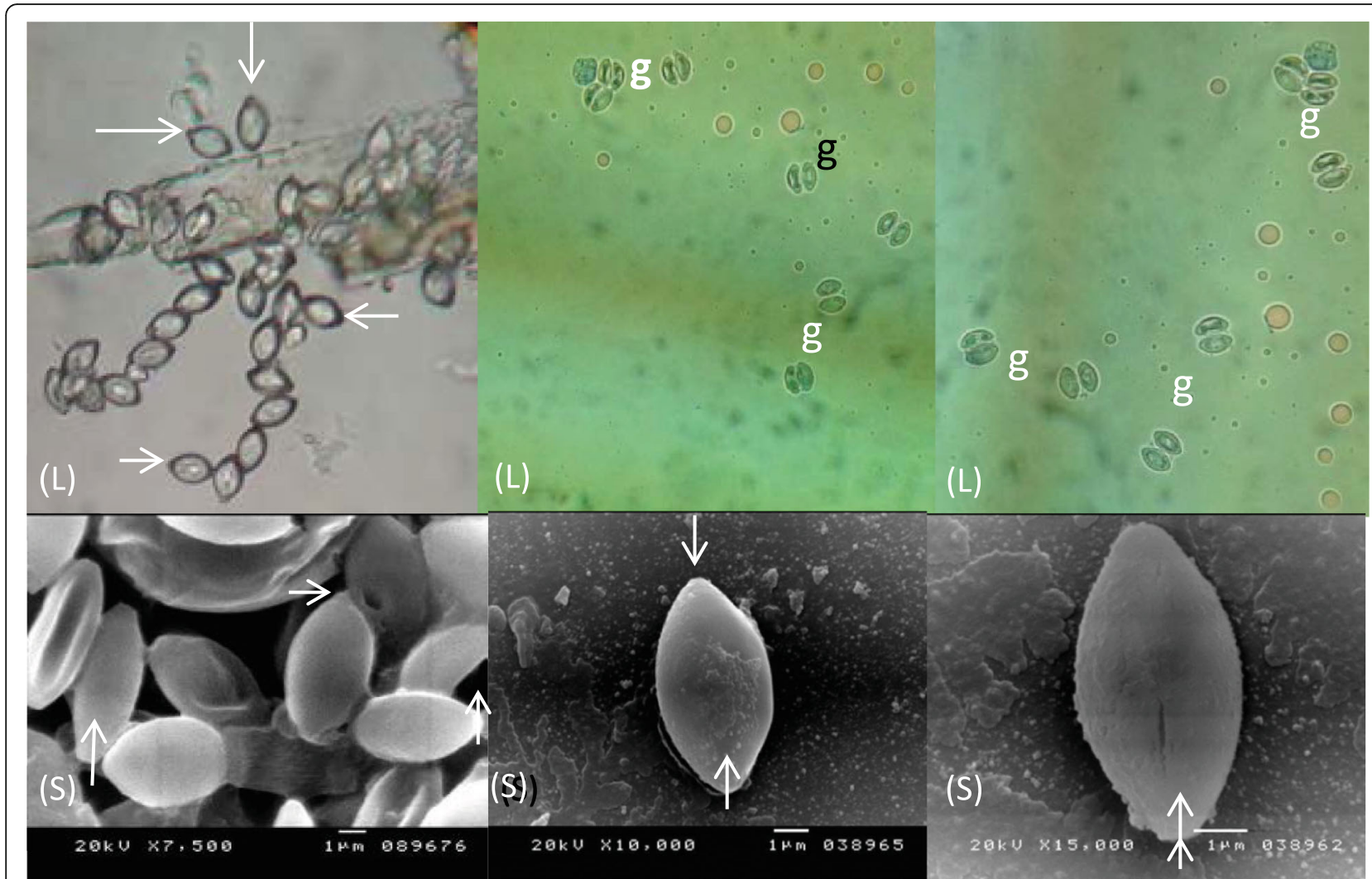

Fig. 2 Light (L) and scanning electron (S) microscope views of Mattesia. Note the navicula-shaped spores with polar plugs (arrows) and spore pairs within a gamontocyst $(\mathrm{g})(\times 400$ magnification)

reported to be attacked by the neogregarine, Mattesia spp. (Finlayson 1950; Lord 2003, 2006). Also, T. castaneum is known to be affected by both the neogregarine, Farinocystis tribolii (Weiser 1953; Rabindra et al. 1981; Njila and Mwansat 2012) and the coccidian, Adelina spp. (Bhatia 1937; Ghosh et al. 2000; Niila and Mwansat 2012).

The literature on host range of the EPP, Mattesia, Nosema, Adelina, or Farinocystis, infecting stored-grain insects, presents no records in this concern from Egypt. Therefore, the present study seems to be the first report of Mattesia sp. on S. zeamais, Adelina sp. on L. turcicus or $R$. dominica, and Nosema sp. on $R$. dominica, in Egypt. Meanwhile, it appears to be the first record for Mattesia sp. in Sitophilus spp. or R. dominica, and Adelina sp. in $R$. dominica.

The present naturally occurring Mattesia-infection in L. turcicus population is congruent with what has been reported by Lefkovitch (1962); on the contrary, Finlayson (1950) mentioned that L. turcicus beetles were apparently not susceptible to Mattesia infection.

Microscopic examination for Mattesia-infected cadavers of the flour-mill beetle, $L$. turcicus reveals that the bodies of these small $(1.5$ to $2.0 \mathrm{~mm}$ ) insect pests would act just as reservoirs for the infective units, spores, of such an EPP, Mattesia sp. Meanwhile, adopting the procedure of smear or water mount preparations (i.e., microscopic examination of the insect body contents) in order to calculate the natural infection rates or to confirm the presence of the protozoan disease causative agent results, vainly, in a great loss in masses of Mattesia and Farinocystis spores, or Adelina oocysts which could be benefited in their mass production. Therefore, to avoid such a technical loss in the protozoan infective units, another procedure was successfully followed. Herein, the microscopic examination, at a magnification of $\times 100$ or $\times 400$, for L. turcicus adults from the ventral side (i.e., via sternites) easily reveals the presence of the characterized lemon-shaped spores of Mattesia species. Mattesia spores can easily be observed through the sterna of the thorax or the abdomen and sometimes in the head (Fig. 6). Furthermore, the same procedure was followed to confirm the presence of both the Adelina oocysts in either L. turcicus adult (Fig. 6) or in T. castaneum adult cadavers (Fig. 7) and the Farinocystis spores of T. castaneum adults (Fig. 7). Pereira et al. (2002) recognized the oocysts of Mattesia sp. through the cuticle in all body regions, especially the head and the appendages of the red imported fire ant, Solenopsis invicta (Hymenoptera: Formicidae). 

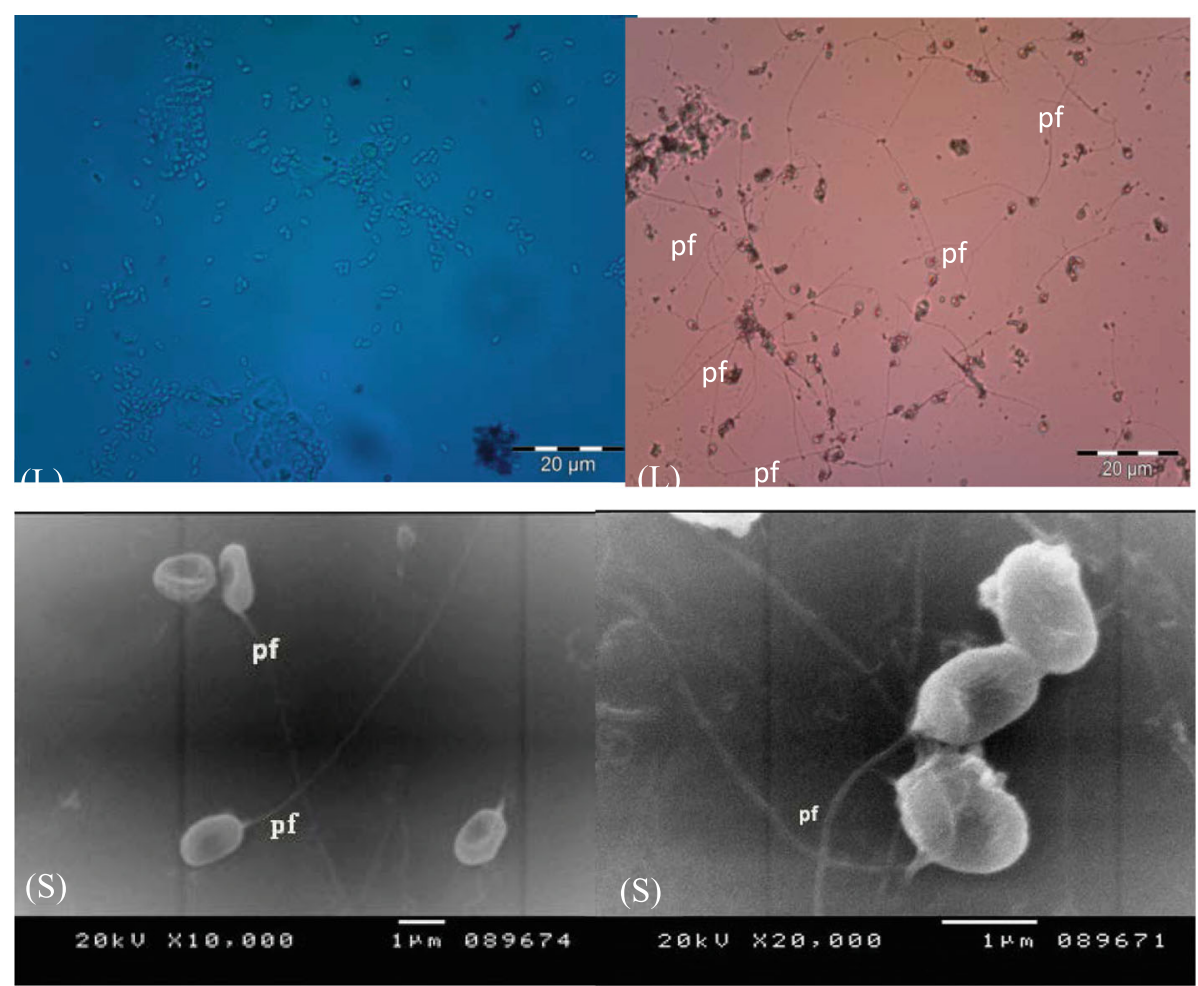

Fig. 3 Light (L) and scanning electron (S) microscope views of Nosema spores isolated from Rhyzopertha dominica. Note the extruded polar filament (pf)

This procedure of detecting the causative agent(s) of certain protozoan diseases will certainly save a considerable quantity of insect cadavers that harbor masses of the infective units of certain EPP which would surely be lost during the classical detection procedure by smears or water mounts. Hence, practically, large numbers of protozoan-infected cadavers could be save to act as reservoirs for producing infective units, spores, or oocysts, in large quantities for microbial control of insect pests in storage.

\section{Spore measurements \\ Mattesia sp.}

The Mattesia spores, originally isolated from L. turcicus, $R$. dominica, S. zeamais, and P. interpunctella were lemon-shaped (navicular) with obvious polar plugs and also formed in pairs within a gamontocyst or gametocyst (Fig. 2).

The Mattesia-spore sizes, as measured from fresh spores, in Ringer solution, or from stained ones, in Lactophenol, are summarized in Table 3. Based on $t$ test data (significant at $1 \%$ level), the differences between fresh-spore sizes of Ringer solution-mounted spores were not significantly consistent with those of Lactophenol-mounted spores (Table 3).

Mattesia spore dimensions for a sample of 50 spores in Ringer solution mounts were measured from $L$. turcicus adults. Their spore sizes ranged in length from 12.5 to $15 \mu \mathrm{m}$ and in width from 7.5 to $10 \mu \mathrm{m}$; with a mean \pm standard deviation (or error) of $14.65 \pm 0.88$ (or 0.12 ) $\times$ $9.85 \pm 0.60$ (or 0.08 ) $\mu \mathrm{m}$. These spore dimensions, in general, were not significantly different (Duncan's multiple range test, significant at $1 \%$ level) from those of $S$. zeamais adults [range, $12.5-15 \times 7.5-12.5 \mu \mathrm{m} ; 14.80 \pm 0.70$ (or $0.10) \times 9.8 \pm 0.99$ (or 0.14$) \mu \mathrm{m}]$, as well as the corresponding Mattesia-spore measurements from $R$. dominica adults [range, $12.5-17.5 \times 7.5-10 \mu \mathrm{m} ; 15.08 \pm 0.92$ (or 0.13 ) $\times$ $9.25 \pm 1.16$ (or 0.16$) \mu \mathrm{m}$ ] or $P$. interpunctella larvae [range, $12.5-17.5 \times 7.5-10 \mu \mathrm{m} ; 14.45 \pm 1.05$ (or 0.15 ) $\times 9.15 \pm 1.20$ (or $0.17 \mu \mathrm{m})$ ]. Exception was recorded for spore widths from $R$. dominica $[9.25 \pm 1.16$ (or 0.16$) \mu \mathrm{m}]$ and $P$. interpunctella $[9.15 \pm 1.20$ (or 0.17 ) $\mu \mathrm{m}$ ] in their fresh, Ringer solution-mounted preparations (Table 3). Their spore widths were significantly not different, but varied significantly, at $1 \%$ level, from their corresponding values of $L$. turcicus $[9.85 \pm 0.60$ (or 0.08$) \mu \mathrm{m}]$ or $S$. zeamais $[9.8 \pm 0.99$ (or 0.14) $\mu \mathrm{m}$ ] (Table 3).

Meanwhile, the corresponding figures for Mattesia-spore dimensions in Lactophenol-mounted preparations for the subject four insect pests were, in general, not significantly different, at 1\% level, Duncan's multiple range test (Table 3); except for spore-widths described from $S$. zeamais $[8.35 \pm$ 1.20 (or 0.17 ) $\mu \mathrm{m}$ ] which were significantly, at $1 \%$ level, wider than those measured from $L$. turcicus $[7.9 \pm 0.49$ (or 

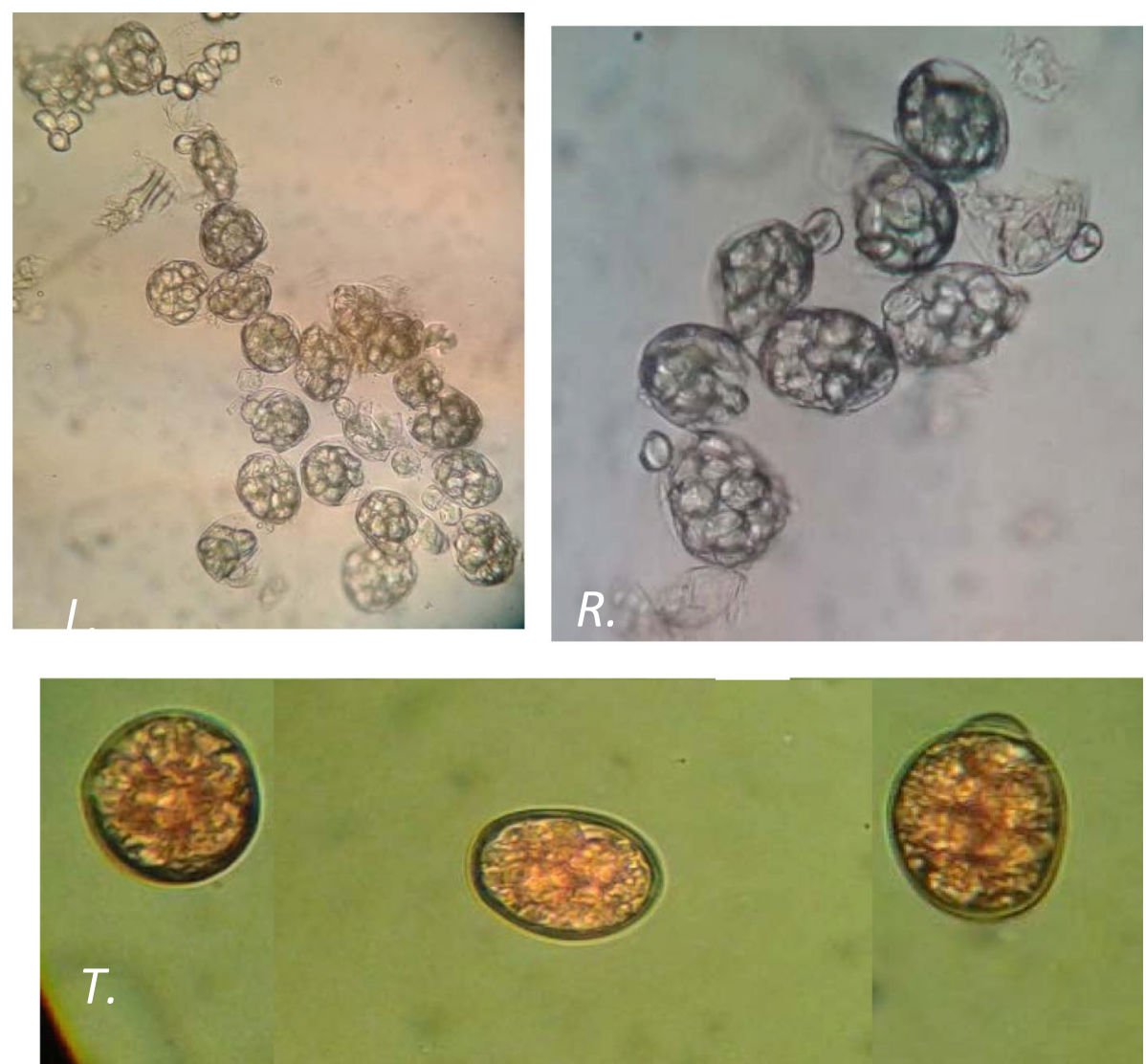

Fig. 4 Light microscope views of Adelina-polysporocystic oocysts isolated from Tribolium castaneum (T.), Rhyzopertha dominica (R.), and aemophloeus turcicus (L.) ( $\times 400$ magnification)

$0.07) \mu \mathrm{m}], R$. dominica $[7.55 \pm 0.35$ (or 0.05$) \mu \mathrm{m}]$, or $P$. interpunctella $[7.5 \pm 0.0$ (or 0.0$) \mu \mathrm{m}]$ (Table 3).

Based on the observations by light and scanning electron microscope, the data illustrated in Table 3 and Fig. 2 reveal that the spores (fresh or stained preparations) of the neogregarine entomopathogen which isolated from the subject four insect pests ( $L$. turcicus, $S$. zeamais, $R$. dominica, and $P$. interpunctella) have the typical characteristics (i.e., navicular shape, polar plugs, one or two spores in the gamontocyst, and spore dimensions) of the genus Mattesia (Order: Neogregarinida; Family: Lipotrophidae).

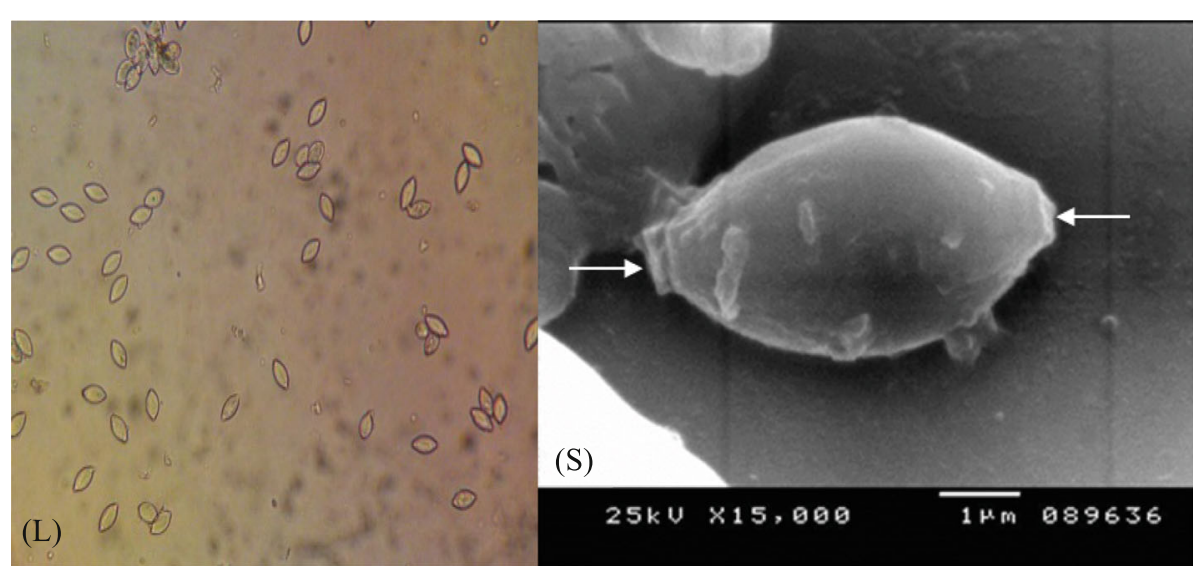

Fig. 5 Light (L) and scanning electron (S) microscope views of Farinocystis spores isolated from Tribolium castaneum (×400 magnification). Note the polar plugs (arrows) 
Table 2 Natural infection rate of Mattesia sp. in both sexes of Laemophlaeus turcicus adults

\begin{tabular}{ll}
\hline Adult beetle sex & $\begin{array}{l}\text { No. of examined beetles } \\
\text { and Mattesia-natural } \\
\text { infection rate (\%) }\end{array}$ \\
\hline Laemophloeus turcicus Female & $145 / 160(90.63)$ \\
Laemophloeus turcicus male & $131 / 144(90.97)$ \\
\hline
\end{tabular}

Levine (1988), Kleespies et al. (1997), and Perkins (2000) noted that the genus Mattesia is one of five genera (Mattesia, Farinocystis, Lipocystis, Lipotropha, and Menzbieria) within the Family Lipotrophidae, in Order Neogregarinida. Members of this Family are characterized by their lemon-shaped (navicular) spores with distinct polar plugs (Fig. 2). On the other hand, Yaman et al. (2012) reported Mattesia as the only genus of the Family Lipotrophidae to have one or two spores within a gamontocyst, whereas members of the other four genera have more than two spores in the gamontocyst.

As the lipotrophid entomopathogen is characterized by its lemon-shaped (navicular) spores with polar plugs, and two spores within one gamontocyst, hence, it simply belongs to the genus Mattesia. This finding is strongly supported by its corresponding data previously reported by Pereira et al. (2002) from the red imported fire ant, Solenopsis invicta; Yaman and Radek (2015) from the great spruce bark beetle, Dendroctonus micans (Kugelann) (Coleoptera: Scolytidae); and Baki (2016) from the common asparagus beetle, Crioceris asparagi (Linne) (Coleoptera: Chrysomelidae). Also, early, Weiser (1955) emphasized that spores occur in pairs are typical of Mattesia species.

On the basis of the size and morphology of the spores, this EPP is identified as belonging to the genus Mattesia; meanwhile, in order to know the type species of this genus, Mattesia, it was necessary to compare the recorded spore sizes, in Table 3, with those previously described species from the available reports on some coleopterous or lepidopterous stored-product hosts (Table 4).

According to spore dimensions shown in Table 3, Mattesia-spore sizes did not, in general, differ significantly among their infected four hosts from stored-grain insect pests. Spore measurements were ranged, in general, between 12.5 and $15.0 \mu \mathrm{m}$ in length and 7.5-10.0 $\mu \mathrm{m}$ in width, and averagely measured from 14.45 to $15.08 \mu \mathrm{m}$ by 9.15 to $9.85 \mu \mathrm{m}$ (fresh-mounts), and from 13.95 to $14.50 \mu \mathrm{m}$ by 7.50 to $8.35 \mu \mathrm{m}$ (stained-mounts) (Table 3 ). These results may indicate that these spores which have been isolated from different stored-product insects, infesting the same arena, are most closely aligned to the same species of the genus Mattesia. Comparatively, such spore dimensions are a little bit larger than those previously described (Table 4) for Mattesia dispora $(12.2 \times 6.7 \mu \mathrm{m})$ from Laemophloeus ferrugineus or L. minutes (Finlayson 1950), but to a large extent are matchable with $M$. dispora (15.4 $\mu \mathrm{m}$ in length) from locusts (Žižka 1978). The spores were also, in their fresh or stained mounts, longer (Table 3) than fresh $(12.0 \times 7.0 \mu \mathrm{m})$ or stained $(10.0 \times 6.0 \mu \mathrm{m})$ spores of $M$. oryzaephili from Oryzaephilus surinamensis (Ormières et al. 1971), as well as they were longer than those of $M$. trogodermae $(11-13 \mu \mathrm{m})$ from Trogoderma granarium (Hall et al. 1971) (Table 4).

M. dispora, $M$. oryzaephili, and $M$. trogodermae are EPP of the fat tissue of insect pests which inhabit stored products (Liu et al. 1974). Morphologically, the differentiating characteristics, spore size, and shape were helpful in distinguishing, tentatively, the present type species of the genus Mattesia from the abovementioned ones. Hence, based on the present results and the published

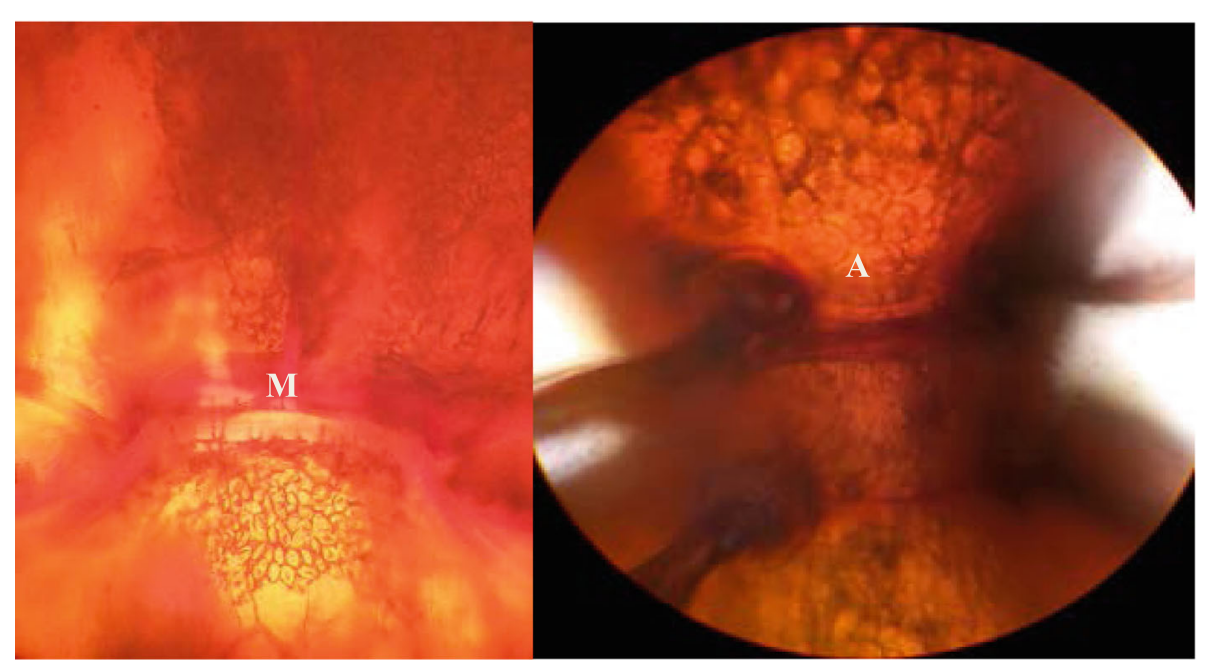

Fig. 6 Light microscope views of Mattesia spores (M) and Adelina oocysts (A) distinctly seen through the sternites of Laemophloeus turcicus beetle $(\times 100$ to $\times 400$ magnification) 


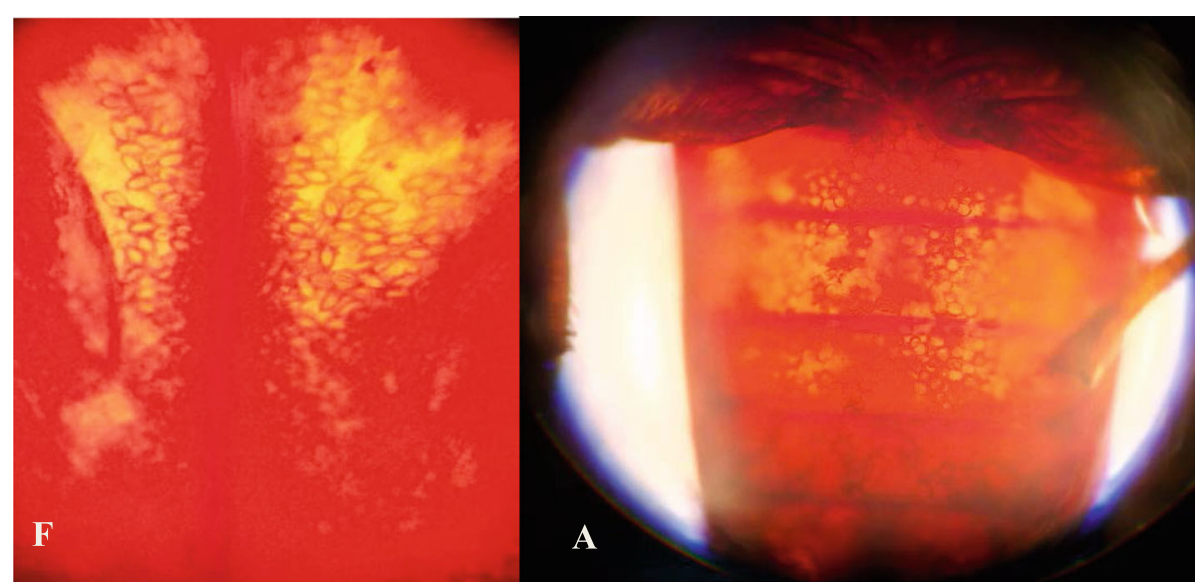

Fig. 7 Light microscope views of Farinocystis spores (F) and Adelina oocysts (A) distinctly seen via the sternites of Tribolium castaneum beetle ( $\times 100$ to $\times 400$ magnification)

ones, the studied lipotrophid entomopathogen could match $M$. dispora; however, confirming or rejecting this identification certainly needs further ultrastructural study on species classification.

In the available literature, there is no Mattesia record, in Egypt, from neither the four insect pests (Laemophlous, Sitophilus, Rhyzopertha, and Plodia) nor others which inhabit stored grains or their products. Hence, the present results may provide, for the first time, the Egyptian arsenal of microbial control agents with a promising EPP, Mattesia, that may be an important limiting biotic factor for a number of insect hosts in storage. Additionally, the remarkable natural prevalence (9-89\%; Table 1) of this entomopathogen, Mattesia, along two successive years (2016 and 2017) and to date, among natural populations of the subject four storage insect pests, may reflect an evidence for a

Table 3 Average spore sizes ( $\mu \mathrm{m}$ ) of Mattesia sp., Farinocystis sp., and Nosema sp. isolated from certain stored-grain insect pests, in fresh and stained smears

\begin{tabular}{|c|c|}
\hline Insect pest and its entomopathogenic protozoan & Mean spore size ${ }^{*}$ length $\pm \mathrm{SD}(\mathrm{SE})^{* *} \times$ width $\pm \mathrm{SD}(\mathrm{SE})$ (range) \\
\hline \multicolumn{2}{|l|}{ Laemophloeus-Mattesia } \\
\hline Fresh & $14.65 \pm 0.88(0.12) a \times 9.85 \pm 0.60(0.08) c(12.5-15) \times(7.5-10)$ \\
\hline Stained & $13.95 \pm 1.20(0.18) b \times 7.6 \pm 0.49(0.07)$ e $(12.5-15) \times(7.5-10)$ \\
\hline \multicolumn{2}{|l|}{ Sitophilus-Mattesia } \\
\hline Fresh & $14.80 \pm 0.70(0.10) a \times 9.8 \pm 0.99(0.14) c(12.5-15) \times(7.5-12.5)$ \\
\hline Stained & $14.40 \pm 1.08(0.15) b \times 8.35 \pm 1.20(0.17) f(12.5-15) \times(7.5-10)$ \\
\hline \multicolumn{2}{|l|}{ Rhyzopertha-Mattesia } \\
\hline Fresh & $15.08 \pm 0.92(0.13) a \times 9.25 \pm 1.016(0.16) d(12.5-17.5) \times(7.5-10)$ \\
\hline Stained & $14.50 \pm 1.01(0.14) b \times 7.55 \pm 0.35(0.05) e(12.5-15) \times(7.5-10)$ \\
\hline \multicolumn{2}{|l|}{ Plodia-Mattesia } \\
\hline Fresh & $14.45 \pm 1.05(0.15) a \times 9.15 \pm 1.20(0.17) d(12.5-15) \times(7.5-10)$ \\
\hline Stained & $14.15 \pm 1.20(0.17) b \times 7.5 \pm 0.0(0.0)$ e $(12.5-15) \times(7.5)$ \\
\hline \multicolumn{2}{|l|}{ Tribolium-Farinocystis } \\
\hline Fresh & $16.95 \pm 1.05(0.15) g \times 12.0 \pm 1.01(0.14) s(15.0-17.5) \times(10.0-12.5)$ \\
\hline Stained & $15.5 \pm 1.01(0.14) h \times 10.1 \pm 1.12(0.16) t(15.0-17.5) \times(10.0-12.5)$ \\
\hline \multicolumn{2}{|l|}{ Rhyzopertha-Nosema } \\
\hline Fresh & $4.32 \pm 0.51(0.07) m \times 2.04 \pm 0.20(0.03) k(4-6) \times(2-3)$ \\
\hline Stained & $3.8 \pm 0.40(0.06) n \times 2.0 \pm 0.0(0.0) k \times(3-4) \times(2)$ \\
\hline
\end{tabular}

*Number of measured spores ranged between 50 and 60 spore. The difference in spore lengths or widths between fresh and stained spores are, in general, significant ( $t$ test; significant at 5 or $1 \%$ level). Data followed by the same letter within column do not differ significantly at $1 \%$ level; Duncan's multiple range test ** Standard deviation of the mean (SD) and standard error (SE) 
Table 4 Summary of spore sizes of Mattesia spp., Farinocystis spp., and Nosema spp. reported in literature from some coleopterous or lepidopterous stored-product hosts

\begin{tabular}{|c|c|c|c|}
\hline Entomopathogenic protozoan species & Spore size $(\mu \mathrm{m})$ & Coleopterous or lepidopterous hosts & References \\
\hline \multirow[t]{2}{*}{ Mattesia dispora } & $12.2 \times 6.7 \mu \mathrm{m}$ & Laemophloeus ferrugineus & Finlayson (1950) \\
\hline & & L. minutes & \\
\hline \multirow[t]{2}{*}{ M. oryzaephili } & $12 \times 7 \mu \mathrm{m}$ (fresh) & Oryzaephilus surinamensis & Ormières et al. (1971) \\
\hline & $10 \times 6 \mu \mathrm{m}$ (stained) & & \\
\hline M. trogodermae & $11-13 \mu \mathrm{m}$ (in length) & Trogoderma granarium & Hall et al. (1971) \\
\hline Mattesia sp. & $\begin{array}{l}12.5-17.5 \times 7.5-12.5 \mu \mathrm{m} \text { (fresh) } \\
12.5-15 \times 7.5-10 \mu \mathrm{m} \text { (stained) }\end{array}$ & $\begin{array}{l}\text { L. turcicus } \\
\text { S. zeamais } \\
\text { R. dominica } \\
\text { P. interpunctella }\end{array}$ & The present study (see Table 3) \\
\hline \multirow[t]{3}{*}{ Farinocystis tribolii } & $12.00-14.40 \times 6.40-8.00 \mu \mathrm{m}$ & Tribolium castaneum & Rabindra and Subramanian (1974) \\
\hline & $13.3-14.3 \times 6.7-7.8 \mu \mathrm{m}$ & Tribolium garnhami & Laird (1959) \\
\hline & $\begin{array}{l}15.0-17.5 \times 10.0-12.5 \mu \mathrm{m} \text { (fresh) } \\
15.0-17.5 \times 10.0-12.5 \mu \mathrm{m} \text { (stained) }\end{array}$ & Tribolium castaneum & The present study (see Table 3) \\
\hline \multirow[t]{8}{*}{ Nosema whitei } & 3.8-5.9 × 2.4-3.6 um (fresh) & Tribolium castaneum & Milner (1972) \\
\hline & 2.9-3.8 × 1.7-2.7 $\mu \mathrm{m}$ (stained) & & \\
\hline & $4.0-6.0 \times 2.3-3.5 \mu \mathrm{m}$ (fresh) & T. confusum & \\
\hline & $3.1-4.1 \times 1.6-2.4 \mu \mathrm{m}$ (stained) & & \\
\hline & $3.0-3.9 \times 1.8-2.7 \mu \mathrm{m}$ (stained) & T. anaphe & \\
\hline & 4.0-5.2 × 2.5-3.6 um (fresh) & Oryzaephilus surinamensis & \\
\hline & 2.7-3.7× 1.8-2.7 $\mu \mathrm{m}$ (stained) & & \\
\hline & $\begin{array}{l}4.0-6 \times 2-3 \mu \mathrm{m} \text { (fresh) } \\
3.0-4 \times 2 \mu \mathrm{m} \text { (stained) }\end{array}$ & Rhyzopertha dominica & The present study (see Table 3) \\
\hline
\end{tabular}

developing epizootic. Therefore, maintaining the protozoan disease in a population is a very requisite demand in this field of control. Fortunately, routes of infection by entomopathogenic protozoans may provide the practical solution of infecting a sufficient proportion of the population, especially through their common method of transmission by scavenger feeding on infected cadavers, where most storedproduct insects are cannibalistic (Fig. 8) (Weiser 1963; Kellen and Lindegren 1971; Henry 1981).

On the other hand, this study provides a clear evidence that the isolated Mattesia sp. has a relatively broad host range that crosses two orders, Coleoptera and Lepidoptera, which include many damaging storedgrain insects (Lord 2003, 2006). That may reveal the importance of this neogregarine entomopathogen as a promising suppressor for a number of insect hosts in storage.

\section{Farinocystis $s p$.}

During the course of the present study, another naturally occurring lipotrophid entomopathogen, Farinocystis, was recorded among cadavers of the red flour beetle, $T$. castaneum. This entomopathogen was found in 50\% and $36 \%$ of the examined samples of $T$. castaneum adults and larvae, respectively (Table 1 ). The morphology of the infective units, spores, has been observed with both the light and the scanning electron microscope (Fig. 5). The shape of such lipotrophid spores was navicular, and the surface sculpture was smooth (Fig. 5). The spores were seen as single forms and not formed in pairs within the gamontocyst, as the case of the abovementioned lipotrophid pathogen, Mattesia sp. (Fig. 2). Polar plugs were also seen (Fig. 5). By means of microscopic examinations at a magnification of $\times 100$ to $\times 400$, the presence of Farinocystis spores in infected cadavers of $T$. castaneum beetles was easily detected through the sternites of these beetles, especially via the abdominal sterna (Fig. 7).

The spores, in their fresh mounts, measure from 15.0 to $17.5 \mu \mathrm{m}$ in length and from 10.0 to $12.5 \mu \mathrm{m}$ in width, with an average of $16.95 \pm 1.05$ (or 0.15 ) $\mu \mathrm{m}$ by $12.0 \pm$ 1.01 (or 0.14 ) $\mu \mathrm{m}$ [mean $\pm \mathrm{SD}$ (or SE); $n=60$ ], while in their stained mounts, they measure from 15.0 to $17.5 \mu \mathrm{m}$ in length and from 10.0 to $12.5 \mu \mathrm{m}$ in width, with an average of $15.5 \pm 1.01$ (or 0.14 ) $\mu \mathrm{m}$ by $10.1 \pm 1.12$ (or 0.16) $\mu \mathrm{m}$ (Table 3). These spore dimensions (Table 3) were longer and wider than those of Farinocystis tribolii (12.00-14.40 $\mu \mathrm{m}$ by $6.40-8.00 \mu \mathrm{m})$ from either $T$. castaneum (Rabindra and Subramanian 1974) or T. garnhami (13.3-14.3 $\mu \mathrm{m}$ by 6.7-7.8 $\mu \mathrm{m}$ ) (Laird 1959) (Table 4). Weiser (1953) was the first to record Farinocystis tribolii on T. castaneum. The type species F. tribolii infects Tribolium spp. and Tenebrio molitor, while the type species 

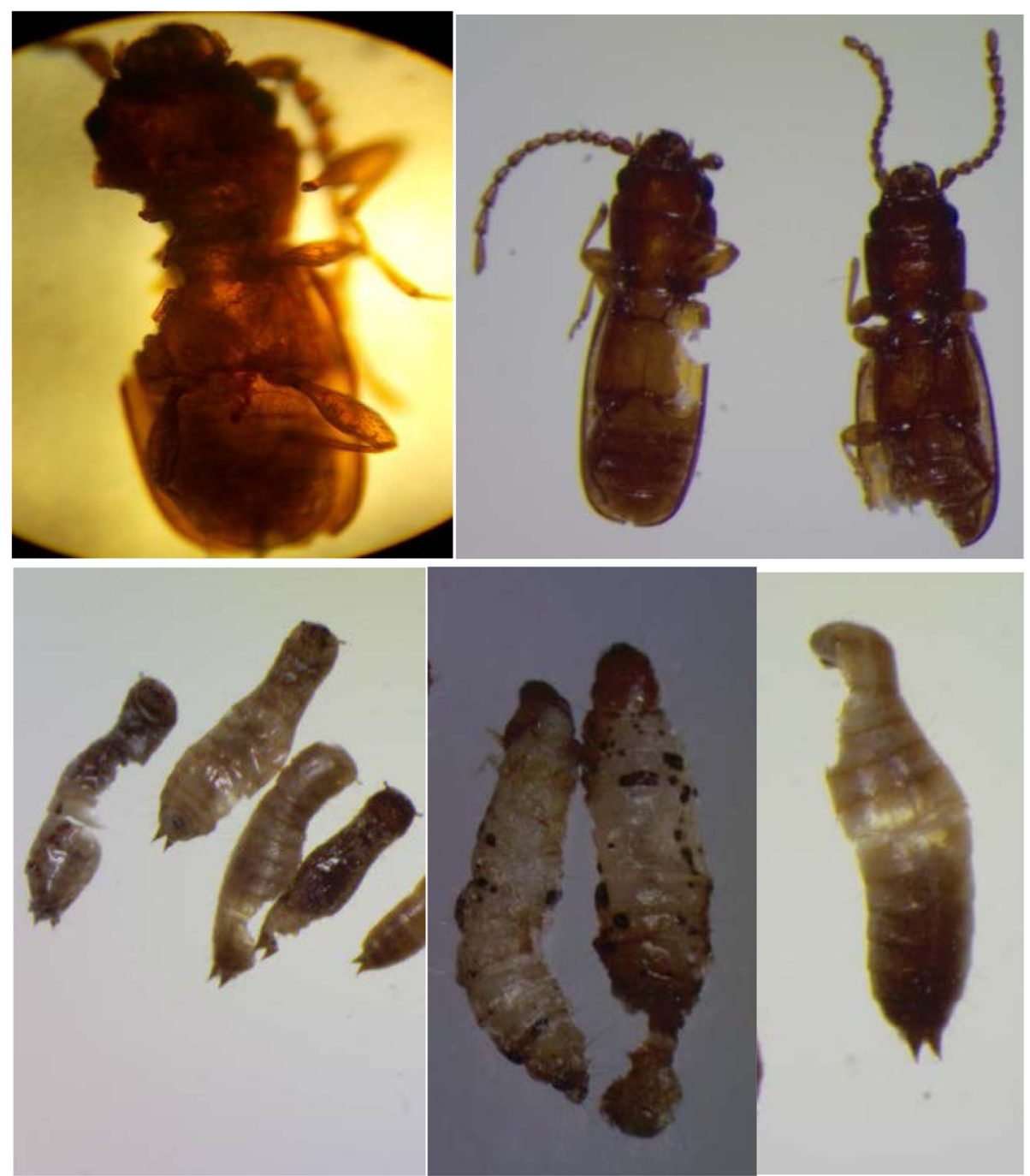

Fig. 8 Cannibalism (scavenger feeding), among most stored-product insects, as a desirable manner to acquire protozoan infection ( $\times 8$ to $\times 40$ magnification)

F. tenebrionides infects Tenebroides muritanicus (Purrini 1976). According to Sprague et al. (1992) that the host provides a further helpful criterion for differentiating species; therefore, the host affinity is generally recognized as a valid taxonomic character. As the neogregarine parasite, F. tribolii has early been described from $T$. castaneum by Weiser (1953); thus, based on the abovementioned criterion, the present Farinocystis might be described tentatively as F. tribolii; however, further study is needed to confirm or reject this finding. There are no available records on $F$. tribolii from Tribolium spp. in Egypt. Therefore, this Farinocystis sp. appears to be the first record of such entomopathogen on T. castaneum in Egypt. The relatively high rates of the recorded natural infection, $50 \%$ or $36 \%$, due to the lipotrophid entomopathogen, Farinocystis sp. among T. castaneum adults or larvae, respectively (Table 1), could potentially be an encouraging source for the microbial control of this insect pest in storage.

\section{Adelina sp.}

The present study has recorded another third EPP, the coccidian, Adelina sp., from three storage insect pests: the red flour beetle, $T$. castaneum; the flour-mill beetle, $L$. turcicus; and the lesser grain borer, $R$. dominica. As shown in Table 1, the natural infection rate was low (14\%) in the examined samples of $L$. turcicus adults, while those of $T$. castaneum adults and larvae or $R$. dominica adults were higher (27 and $60 \%$ or $34 \%$, in respect) than the corresponding rate for $L$. turcicus.

The presence of the characteristic adeleid polysporocystic oocysts in their fresh or stained mounts was the evidence of the coccidian infection (Fig. 4). Meanwhile, by means of the 
light microscopy, at a magnification of $\times 100$ to $\times 400$, Adelina oocysts were easily seen via the sternal side of infectedadults of both L. turcicus and T. castaneum (Figs. 6 and 7), but with $R$. dominica-infected adults, this procedure was not helpful as the adult integument is heavily sclerotized. Seemingly, this procedure is useful in mass production program of the entomopathogenic coccidian, Adelina, and neogregarines, Mattesia or Farinocystis from their insect hosts which possess less sclerotized integuments, as in Laemophloeus or Tribolium adults in the present study.

Three species of the genus Adelina have been described from tenebrionid beetles. One is A. tenebrionis from $T$. molitor (Sautet 1930); the second one is A. tribolii from Tribolium ferrugineum (Bhatia 1937); and the third species is A. castana from T. castaneum (Ghosh et al. 2000). Therefore, to decide whether the present Adelina species is belonging to $A$. tribolii or $A$. castana or may be to another different species, future study should be carried out to verify such taxonomal status.

Although Adelina spp. have been described from Tribolium spp. and other coleopterous pests in storage, as abovementioned, but in the literature, there are no reports on such a coccidian parasite, Adelina from L. turcicus or $R$. dominica. There is only one report from Kosova, Yugoslavia by Purrini (1977) about $A$. tribolii which was found infecting $L$. ferrugineus. Therefore, this study appears to be the first report of this coccidian entomopathogen on $L$. turcicus and $R$. dominica as well as its first record from $T$. castaneum, L. turcicus, and R. dominica in Egypt.

Adelina-natural infection rates presented in Table 1 (14-60\%) could nominate this entomopathogen as an important third limiting biotic factor for the studied storage insect hosts. Such a relatively broad host range of the coccidian entomopathogen, Adelina sp., offers a reasonable possibility for its role to suppress some of the most abundant and damaging insect pests of stored grains or their products. A similar supportive result has been reported by Henry (1981) for the coccidian A. tribolii which infects several stored-product pests and causes striking epizootics in Tribolium populations. The author recorded infection rates of $68 \%$, indicating that this coccidian pathogen is an important factor in the regulation of laboratory and natural populations of Tribolium spp.

\section{Nosema sp.}

The microsporidian entomopathogen, Nosema sp. (Fig. 3), is the fourth entomopathogenic protozoan recorded in this study. This nosematid entomopathogen has been isolated only from adults of the lesser grain borer, $R$. dominica. As shown in (Table 1), the Nosema-infection rate, among the examined naturally dead adults, was low where 83 of 775 adult cadavers were found to be infected by this entomopathogen with a prevalence of about $11 \%$.
Based on reviewing the available literature, the microsporidian entomopathogen, Nosema sp., observed in this study seemingly is the first record from $R$. dominica in Egypt, but also the second record on the basis of the other countries. Lipa (1968) was the only author that reported Nosema weiseri sp. n. from $R$. dominica.

Microscopic examination of $R$. dominica adult cadavers revealed the presence of microsporidian spores. When the infected beetles were squashed in Ringer solution, a huge number of the characteristic Nosema spores (Fig. 3) were released on the microscopic slide.

The isolated Nosema sp. was characterized for identification according to its spore morphology. When Nosema spores were examined by the light or the scanning electron microscope, their shapes appeared to be oval with a smooth surface sculpturing. The polar filament of Nosema was also observed (Fig. 3). Fresh spores measured $4.32 \pm 0.51$ (or 0.07$) \mu \mathrm{m}(4-6 \mu \mathrm{m})$ in length and $2.04 \pm 0.20$ (or 0.3$) \mu \mathrm{m}(2-3 \mu \mathrm{m}$ ) in width (mean $\pm \mathrm{SD}$ (or SE) (range), while the corresponding spore dimensions in their Lactophenol preparations were $3.8 \pm 0.40$ (or 0.06) $\mu \mathrm{m}(3-4 \mu \mathrm{m}$ ) in length and $2.0 \pm 0.0$ (or $0.0) \mu \mathrm{m}(2 \mu \mathrm{m})$ in width (Table 3). The differences between spore sizes measured from fresh spores in Ringer solution smears were not consistent with those measured from stained spores in Lactophenol smears ( $t$ test; significant at 5\% level). As seen in Tables 3 and 4 , the Nosema spore size for $R$. dominica, whether from fresh or stained smears, seemingly not moderately differs from those previously studied by Milner (1972) in other storage insect hosts, Tribolium spp. and O. surinamensis (Table 4). Yaman and Radek (2003) reported the spore dimension as a good character for comparison Nosema species. Unfortunately, the spore size of $N$. weiseri which has been reported by Lipa (1968) from $R$. dominica is not available. Based on the present spore measurements from infected $-R$. dominica adults, in Table 3, as well as those published by Milner (1972) for Tribolium spp. and O. surinamensis (Table 4); also, taking into consideration the findings of Milner (1972) which reveal that the effect of host species on the Nosema morphology, including spore size, is insignificant, therefore, the present study may suggest Nosema whitei as a tentative type species of the genus Nosema. However, confirming or rejecting this suggestion certainly needs further ultrastructural study on species classification. In this concern, Yaman and Radek (2003) had considered the spore as the most important life cycle stage for the identification of microsporidia by ultrastructural studies or host range studies.

Summarily, the natural occurrence of protozoan diseases, with low or high infection rates (9-89\%), among insect pest populations of stored grains is documented in the present study. Four EPP belong to different genera, Mattesia, Farinocystis, Adelina, and Nosema, were 
recorded, for the first time in Egypt, from economically destructive five stored-product insect pests (L. turcicus, $T$. castaneum, $R$. dominica, S. zeamais, and P. interpunctella). Cadavers of the subject protozoan-infected stored-grain insect pests seemingly act as reservoirs full of huge numbers of protozoan infective units, spores, or oocysts. They could easily be seen through hosts' sterna that possess a less sclerotized integument (e.g., L. turcicus and T. castaneum). Also, from the microbial control standpoint, a periodic isolation for the local strain(s) of the entomopathogenic protozoans associated with stored-grain insect pests is important for monitoring such promising biological control agents.

\section{Conclusions}

Stored insect pests harbor promising varieties of (EPP), including neogregarines (e.g., Mattesia spp. and Farinocystis spp.), coccidia (e.g., Adelina spp.), and microsporidia (e.g., Nosema spp.). The protozoan natural infection rates among populations of some coleopterous and lepidopterous storedgrain pests range from relatively low incidences to high or epizootics. From the microbial control standpoint, a periodic isolation for the local strain(s) of the entomopathogenic protozoans associated with stored-grain insect pests is important for monitoring such promising biological control agents. Hence, Egypt could possess its own arsenal of local microbial control agents (i.e., EPP or others) to suppress, through natural or applied measures, the populations of insect pests in storage.

\section{Acknowledgements}

Not applicable

\section{Authors' contributions}

All authors agreed to publish the manuscript. All authors read and approved the final manuscript.

\section{Funding}

Not applicable

\section{Availability of data and materials}

Not applicable

Ethics approval and consent to participate

Not applicable

\section{Consent for publication}

Not applicable

\section{Competing interests}

The authors declare that they have no competing interests.

Received: 29 May 2019 Accepted: 5 January 2020

Published online: 24 January 2020

\section{References}

Baki H (2016) A new neogregarine entomopathogen from Crioceris asparagi (Linne, 1758) in Turkey. J Agric Sci Tech. A6:11-17

Bhatia ML (1937) On Adelina tribolii, a coccidian parasite of Tribolium ferrugineum F. Parasitology 29:239-246
Finlayson LH (1950) Mortality of Laemophloeus (Coleoptera, Cucujidae) infected with Mattesia dispora Naville (Protozoa, Schizogregarinaria). Parasitology 40: 261-264

Flinn PW, Schöller M (2012) Biological control: insect pathogens, parasitoids, and predators. Kansas State University Agricultural Experiment Station and Cooperative Extension Service S156:1-10

Ghosh CM, Choudhury A, Misra KK (2000) Life histories of three new coccidian parasites from three coleopteran stored-grain pests of India. Acta Protozool 39:233-240

Hall IM, Stewart FD, Arakawa KY, Strong RG (1971) Protozoan parasites of species of Trogoderma in California. J Invertebr Pathol 18:252-259

Henry JE (1981) Natural and applied control of insects by protozoa. Annu Rev Entomol 26:49-73

Kellen WR, Lindegren JE (1971) Modes of transmission of Nosema plodiae Kellen and Lindegren, a pathogen of Plodia interpunctella (Hübner). J Stored Prod Res 7:31-34

Khan AR, Selman BJ (1989) Nosema spp. (Microspora:Microsporidia: Nosematidae) of stored product Coleoptera and their potential as microbial control agents. Agric Zool Revs 3:193-223

Kiraly Z, Klement Z, Solymosy F, Voros J (1970) Methods in plant pathology with special reference to breeding for disease resistance. Akademiai Kiado, Budapest, pp 161-166

Kleespies R, Huger AM, Buschinger A, Nähring S, Schumann RD (1997) Studies on the life history of a neogregarine parasite found in Leptothorax ants from North America. Biocontrol Sci Tech 7:117-129

Laird M (1959) Gregarines from laboratory colonies of flour beetles, Tribolium castaneum (Herbst) and T. confusum Duval, at Montreal. Can J Zool 37: 378-381

Lefkovitch LP (1962) The biology of Cryptolestes turcicus (Grouvelle) (Coleoptera: (ucujidae), a pest of stored and processed cereals. Rev Appl Entomol 50:658

Levine ND (1988) The protozoan phylum Apicomplexa. In: 2, CRC Press. Raton, Boca

Lipa JJ (1968) On two microsporidians; Nosema whitei Weiser from Tribolium confusum, and Nosema weiseri sp. n. from Rhizopertha dominica. Acta Protozool 5:375-380

Liu HJ, Macfarlane RP, Pengelly DH (1974) Mattesia bombi n. sp. (Neogregarinida: Ophrocystidae), a parasite of Bombus (Hymenoptera: Apidae). J Invertebr Pathol. 23:225-231

Lord JC (2003) Mattesia oryzaephili (Neogregarinorida: Lipotrophidae), a pathogen of stored-grain insects: virulence, host range and comparison with Mattesia dispora. Biocontrol Sci Tech 13:589-598

Lord JC (2006) Interaction of Mattesia oryzaephili (Neogregarinorida: Lipotrophidae) with Cephalonomia spp. (Hymenoptera:Bethylidae) and their hosts Cryptolestes ferrugineus (Coleoptera: Laemophloeidae) and Oryzaephilus surinamensis (Coleoptera: Silvanidae). Biol Control 37: 167-172

McLaughlin, R. E. 1971. Use of protozoans for microbial control of insects. In "Microbial control of insects and mites", Burges, H.D. and Hussey, N.W. Academic Press, New York, 151-172

Milner RJ (1972) Nosema whitei, a microsporidian pathogen of some species of Tribolium. I. Morphology, life cycle, and generation time. J Invertebr Pathol 19:231-238

Nijla HL, Mwansat GS (2012) Evaluation of some protozoan pathogens of Tribolium castaneum (Herbst) (Coleoptera: Tenebrionidae) and Dermestes maculates Degeer.(Coleoptera: Dermestidae) as possible biocontrol agents. Int J Appl Res Technol 1(2):174-179

Ormières R, Louis C, Kuhl G (1971) Mattesia oryzaephili n. sp., néogregarine parasite d'Oryzaephilus surinamensis L. (Coleoptera : Cucujidae). Cycle et action pathogéne. Bull Soc Zool Fr 96:547-556

Pereira RM, Williams DF, Becnel JJ, Oi DH (2002) Yellow-head disease caused by a newly discovered Mattesia sp. in populations of the red imported fire ant, Solenopsis invicta. J Invertebr Pathol 81:45-48

Perkins, F.O. 2000. Order Neogregarinida Grasse, 1953. In "an illustrated guide to the Protozoa", Lee, J. J., Leedale, G. F., and Bradbury, P. 2nd, Society of Protozoologists, Lawrence, 288-298

Purrini K (1976) Zur kenntnis der insektenfauna und ihre krankheiten in einigen alten muhlen des Kosova gebietes, Yugoslawien. Acta Phytopathologica Academiae Scientiarum Hungaricae 11(3-4):305-315

Purrini, K. 1977. Adelina tribolii Bhatia and A. mesnili Perez (Sporozoa, Coccidia) as pathogens in insect pests of stored products in the Kosova district, Yugoslavia. Rev Appli Entomol, 65(2): 886 
Rabindra RJ, Balasubramanian M, Jayaraj S (1981) The effects of Farinocystis tribolii on the growth and development of the flour beetle Tribolium castaneum. J Invertebr Pathol 38(3):345-351

Rabindra RJ, Subramanian TR (1974) First record of the gregarine Farinocystis tribolii Weiser on Tribolium castaneum (Herbst)from India. Curr Sci 43:688-689

Ramanujam B, Rangeshwaran R, Sivakmar G, Mohan M, Yandigeri MS (2014) Management of insect pests by microorganisms. Proc Indian Nat Sci Acad 80(2):455-471

Sautet J (1930) Adelina tenebrionis n. sp., parasite du coelome de la larva de Tenebrio molitor. Annls Parasit Hum Comp 8:241-243

Sprague V, Beenel JJ, Hazard El (1992) Taxonomy of phylum Microspora. Crit Rev Microbiol 18:285-395

Weiser J (1953) Parasites of the flour beetle Tribolium castaneum. Proc Soc Protozool 4:21

Weiser J (1955) A new classification of the Schizogregarina. J Protozool 1:6-12

Weiser, J. 1963. Sporozoan infections. In: "Insect pathology: an advanced treatise". II, Steinhaus, E. A. Academic Press, London, 291-331

Weiser, J., Bucher, G.E., and Poinar, G.O. 1976. Host relationships and utility of pathogens. In "The theory and practice of biological control", Huffaker, C.B. and Messenger, P.S., Academic Press, New York, 169-185

Yaman M, Radek R (2003) Nosema chaetocnemae sp. n.(Microspora: Nosematidae), a microsporidian parasite of Chaetocnema tibialis (Coleoptera: Chrysomelidae). Acta Protozool 42:231-237

Yaman M, Radek R (2015) Mattesia weiseri sp nov., a new neogregarine (Apicomplexa: Lipotrophidae) pathogen of the great spruce bark beetle, Dendroctonus micans (Kugelann) (Curculionidae: Scolytinae). Parasitol Res. 114(8):2951-2958

Yaman M, Radek R, Linde A (2012) A new neogregarine pathogen of Rhizophagus grandis (Coleoptera: Monotomidae). North-Western J Zool 8: 353-357

Žižka Z (1978) Examination of the cyst of Malamoeba locustae and of the spore of Mattesia dispora with the scanning microscope. J Invertebr Pathol 32:119-123

\section{Publisher's Note}

Springer Nature remains neutral with regard to jurisdictional claims in published maps and institutional affiliations.

\section{Submit your manuscript to a SpringerOpen ${ }^{\circ}$ journal and benefit from:}

- Convenient online submission

- Rigorous peer review

- Open access: articles freely available online

- High visibility within the field

- Retaining the copyright to your article

Submit your next manuscript at $\boldsymbol{\nabla}$ springeropen.com 